\title{
Limited Business Knowledge Investors' Perceptions Of Auditor Independence In The Provision Of Assurance On Unregulated Nonfinancial Disclosures
}

Reginald Wilson, University of Southern Mississippi, USA

\begin{abstract}
Vasarhelyi and Zheng (2013) report that more than 4,000 filing errors have been reported in XBRL interactive data following the U.S. Securities and Exchange Commission's 2009 interactive data reporting mandate. Alles and Gray (2012) report that demand exists for externally provided assurance of XBRL filings if the cost of assurance appears less significant to clients. While the discussion of assurance on XBRL filings generally addresses management's confidence in the accuracy assurance on financial data, a void in the literature exists regarding auditor independence in the provision of assurance on XBRL-generated nonfinancial information. Further, Pinsker and Wheeler (2009) note that limited business knowledge (LBK, hereafter) investors' perceptions of - and reactions to - assurance services have not been fully examined. The results of the present research indicate that LBK investors may be more tolerant of a nonindependent attestation on XBRL nonfinancial data with respect to their long-term investments, but not necessarily for their short-term investments. In addition, companies that provide assurance on voluntarily reported nonfinancial information may feel a level of comfort in the fact that LBK investors do not feel that they would win a lawsuit against the company for a mistake in this information.
\end{abstract}

Keywords: Auditor Independence; Nonfinancial Disclosures; Limited Business Knowledge Investors; Nonprofessional Investors

\section{INTRODUCTION}

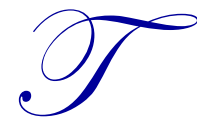

he American Institute of Certified Public Accountants (AICPA, hereafter) recently examined the current state of business reporting and assurance to identify key forces of change and limitations that the profession must overcome in order to better address the needs of financial statement users in the $21^{\text {st }}$ century (Pawlicki 2008). The AICPA specifically states that the accounting profession must modernize its reporting model and address the need for timelier reporting and new audit strategies (Pawlicki 2008, 4). The report also singles out advances in technology and market reactions as the top issues driving the change in reporting and assurance models.

The current research examines limited knowledge investors' (LBK investors, hereafter) perception of continuous assurance on a company's voluntary, XBRL-generated nonfinancial disclosures. ${ }^{1}$ This study is

\footnotetext{
${ }^{1}$ The AICPA's Special Committee on Assurance Services (hereafter SCAS) defines assurance services as "independent professional services that improve the quality of information, or its context, for decision makers (Alles et al. 2002)." SCAS claims that the scope of assurance services involves any type of information (financial or nonfinancial), and that "the goal of assurance services is information improvement, not the issuance of a report on it" (although an assurance report may be issued through a contractual agreement). Hunton et al. (2004) states that the term continuous means that "assurance is provided 'in real time' as information is generated or updated, or aggregated at intervals less frequently than quarterly or annually generated data." The present study employs Hunton et al.'s (2004) definition of assurance, which operationalizes assurance as "assurance that is attached to full or partial financial information releases."
} 
motivated by Pinsker and Wheeler $(2009,46)$, who suggest future research as to whether a stronger form of expanded assurance positively affects LBK investors' investment decisions. The study also answers their call for future research regarding the value of expanded assurance.

Pinsker and Wheeler (2009; hereafter PW 2009) define LBK investors as those with limited business knowledge and experience about current business practices and business-related IT services. Research suggests that LBK investors' perceptions of and reactions to assurance services have not been fully examined, as this group has only recently been identified as a subset of less sophisticated investors.

The present study specifically focuses on LBK investors for two reasons. First, extant literature reveals the need for researchers to decompose nonprofessional individual investors into subgroups, since each group has a different level of accounting knowledge (Elliot et al. 2007; Ackert and Church 2001; Hunton and McEwen 1997).

Second, LBK investors are important because the Sarbanes-Oxley Act of 2002 stresses the need to protect investors who do not have the necessary knowledge to protect themselves. Pawlicki $(2008,13)$ suggests that there has been an increase in new investors, by way of those who participate in their 401(k) plans. Regrettably, LBK investors tend to lack formal accounting training, which makes them more apt to misunderstand or ignore knowledge associated with current business practices and related information technology. Therefore, it is important that accounting regulators understand LBK investors' determinants of demand for continuous assurance in order to assist them in their investment decisions.

It is unknown, however, whether LBK investors are willing to pay a premium for assurance services not required on voluntarily reported disclosures in XBRL. Further, it is unknown whether continuous assurance providers' level of independence would affect their decision to purchase assurance for non-regulated nonfinancial assurance. Bhattacharya et al. (2007) find that less sophisticated investors are more vulnerable than sophisticated investors to be deceived by misleading, unaudited proforma earnings information. Thus, this research addresses LBK investors' perceptions of the credibility of the assurance provided by the following sources: a company's voluntarily reported, XBRL-generated nonfinancial disclosures: management-provided assurance (i.e. no external assurance), continuous controls monitoring, or an independent auditor.

The results of this research indicate that LBK investors may be more tolerant of a non-independent continuous assurance arrangement for their long-term investments, but not necessarily for their short-term investments. In addition, LBK investors are not convinced that they would win a lawsuit in which they suffer losses a company's honest mistake from their voluntary continuous reporting system.

The remainder of this paper is organized as follows. The next section provides a review of the background and hypotheses. The following section discusses the methodology. The research concludes with a discussion of the results, followed by the conclusion.

\section{BACKGROUND AND HYPOTHESES}

Alles et al. (2002) suggest that three components are essential to effective provision of assurance services: (1) capturing information by the assuree, (2) monitoring and analyzing information by the assuror to ensure the reliability of the information, and (3) communicating the outcome of the assurance engagement by the assuror. This study focuses on the third component of assurance (communication) for the following reasons.

First, communication must come from a reliable source in order for the information to be useful to the investor. Investors who perceive information bias when management communicates information about their own company tend to penalize the company by lowering the stock prices for unreliable information (Miller 2002). However, when information is reliable, stock prices tend to more accurately reflect investors' perceived value of a company (King et al. 1990; Olsen 1997). Hence, this research examines LBK investors' perceptions of the credibility of various continuous assurance providers. 
A second reason for focusing on the communication of assurance is that the credibility of a continuous assurance provider reduces both information risk and stock price volatility. Alles et al. (2002) invoke that independent assurance may not be necessary in certain situations where management's signals alone are sufficiently reliable.

A third reason for studying the communication of assurance is to understand factors that increase the demand for continuous assurance. Alles et al. (2002) assert that investors' demand for continuous assurance may be a key driver of continuous assurance. For these reasons, the current research examines LBK investors' determinants of demand for continuous assurance on XBRL-generated nonfinancial information.

\section{Management Credibility}

Auditing research finds that investors compensate for their uncertainty regarding management's bias in reporting, especially in the absence of independent assurance (Boylan 2000; Dopuch and King 1991; Hasan et al. 2003; Hovland et al. 1953). Investors are assumed to asign varying degrees of credibility to information based on two factors: (1) the source (or provider) of the information, and (2) based on whether the purported information is positive or negative (i.e. the direction of the information). While required financial statement information and mandatory financial statement disclosures are regulated by accounting standards, voluntarily-reported nonfinancial information is not subject to SEC regulations. This may adversely affect investors' perceptions of the credibility of nonfinancial information in the absence of an independent assurance provider.

Multiple research streams have examined the issue of management credibility using psychology research. Williams (1996) and Hirst et al. (1999) find that management credibility is a significant factor in assessing the credibility of a firm's financial disclosures, while Healy and Wahlen (1999) find that management's credibility may be affected by incentives to disclose information in the most positive manner. Other studies find investors' perceptions of financial statement reliability decrease in the presence of certain management compensation structures; their perception of information risk is reflected in stock price volatility (Hirst et al. 1999; King et al. 1990; Masters 1989; Miller 2002; Olsen 1997, Pinsker and Wheeler 2009). Consistent with prior research (Akerlof 1970), these findings suggest that LBK investors may penalize management's assertions regarding negative information disclosures if it is suspected that management may not be as forthcoming in their disclosure information as a result of incentives to present the negative information in a more positive light.

In addition to psychology research, Hunton et al. (2008) find that earnings management behavior is reduced with continuous monitoring, compared to periodic monitoring in the presence of short-term incentives. They also find that more frequent monitoring significantly decreases the willingness of managers to continue to use a risky but viable project.

A company's continuous reporting system provides investors with nonfinancial information that is not subject to regulation. Even though this information is not regulated, two mechanisms - continuous controls monitoring and continuous assurance - may positively influence investors' perceptions of the credibility associated with management's voluntary reporting of continuously reported data.

\section{Management's Provision of Continuous Controls Monitoring}

Continuous controls monitoring (CCM, hereafter) is designed to track financial and nonfinancial information that flows through a company's information system. Continuous controls monitoring differs from continuous assurance. Continuous assurance is designed to improve the quality of information by providing assurance about the information "in real time" as information is generated or updated. Continuous controls monitoring is an approach to ensuring that the financial information generated by publicly traded companies meet the requirements of the Sarbanes-Oxley Act.

Investors' perceptions of management's assertions about continuous reporting information may be improved in the presence of CCM. When effective, CCM provides external auditors, internal auditors, and corporate managers with real-time status assurances for all of managements' compliance control points, and alerts 
these user groups of material events and other occurrences (Hunton et al. 2008). In addition, CCM may be used to drive significant business improvement, since it is a tool for ensuring that critical business processes are being executed and ethically adhered to (Huffman and Crump 2005).

PWC (2006) finds that 81 percent of organizations reported that their internal auditors have either implemented or plan to implement continuous monitoring. While CCM can be used to monitor a company's processes that generate continuous reporting information at all times, the following limitations are associated with CCM systems: (1) lack of timeliness, (2) the extent of information given by the system, and (3) and inability to check all control points (Huffman and Crump 2005). ${ }^{2}$ In addition to these limitations, management may view their company's internal audit function as a means of achieving operational goals and generating cost savings (Hermanson and Rittenberg 2003). These limitations may cause investors to be leery of trusting a CCM system that is run by the company's internal audit department.

\section{Independent Assurance}

Extant literature finds that the presence of certified public accountants positively affects a firm's value (Simunic and Stein 1987; Slovin et al. 1990), and that investors highly value CPA audits as a credible source of information (Dopuch and King 1991; Boylan 2000; Hasan et al. 2003; Pany and Smith 1982; Hodge 2001). PW (2009) find that an independent CPA review engagement significantly increases LBK investors' perceptions of stock value. They also find that stock prices increase significantly when positive nonfinancial information disclosures are provided by an independent CPA review engagement, which is consistent with psychology research (Birnbaum and Stegner 1979). In addition, their research finds that expanded assurance decreases stock price variance when negative nonfinancial information is disclosed.

\section{Continuous Assurance Hypothesis}

Two conflicting lines of reasoning exist regarding whether a provider of continuous assurance on continuous reporting information should be independent. The traditional line of reasoning - which is supported by prior literature - is that independence is essential to the reliability of work performed in an attest engagement.

Taylor et al. (2003) propose a second line of reasoning as they set forth their argument for a new framework that emphasizes financial statement reliability. They hypothesize that independence (and expertise) underlies a CPAs pursuit of objectivity, which leads to useful, reliable financial statements.

The present research hypothesizes that Taylor et al.'s (2003) second line of reasoning is more in line with LBK investors' preference for continuous provided assurance. LBK investors - similar to small businesses - are not as astute about accounting practices as are their more sophisticated counterparts. While it is possible that both LBK investors and non-SEC companies may believe that a CPA can provide an objective review while not being independent, their more sophisticated investors (CPAs and SEC companies) have different opinions. However, financial statement users expect CPAs to exhibit a high level of integrity, even in the midst of recent accounting scandals, thus leading to better quality continuous reporting information resulting from a non-independent review engagement. The following hypothesis presents this line of reasoning, as follows:

H1: LBK investors' confidence in continuously reported, XBRL-generated, nonfinancial information increases when continuous assurance is provided by a non-independent CPA review engagement.

\section{Continuous Assurance Demand Hypothesis}

Hunton et al. (2004) assert that value is attached to accounting behavioral researchers who explore how continuous assurance may improve decision quality with more frequent reporting. They also note that "researchers know little about the perceived incremental value of continuous assurance in the context of more frequent financial

${ }^{2}$ Future research may focus on strategies to overcome these limitations and how this increases the credibility of CCM. 
reporting." Birnbaum and Stegner (1979) and Mercer (2004) find that disclosure source is only one factor in the decision process.

This research contributes to the literature stream by modeling LBK investors' determinants of their demand for purchasing continuous assurance. The following research question addresses this concern.

H2: What are LBK investors' determinants of demand for an investor to be willing to purchase continuous assurance on a company's continuously-reported, voluntary nonfinancial information?

\section{METHODOLOGY}

\section{Participants}

The selection of participants for this study is consistent with PW (2009) and Ackert and Church (2001), who use liberal arts students as a proxy for non-business individuals. This group is a proxy for LBK investors, who are nonprofessional investors with a limited background in business and/or accounting, and who are purchasing (or someday may purchase) common stock securities. Participants are randomly selected senior liberal arts students.

\section{Procedures and Statistical Methods}

Participants are asked to complete a survey consisting of twenty-two closed-ended statements in order to understand LBK investors' determinants of demand for continuous assurance on continuously reported information. Participants are asked to assess each using a 5-point Likert Scale, anchored at $1=$ strongly disagree, and $5=$ strongly agree. Factor analysis is an appropriate technique that may be used to determine whether information can be condensed or summarized in a smaller set of factors or components. In addition, it is an appropriate technique that can be used to examine the underlying relationships for a large number of variables. Appendix A summarize the participants' responses to each of the survey items.

\section{RESULTS ${ }^{3}$}

\section{Factor Analysis}

An analysis of the eigenvalues reveals that six eigenvalues over one are eligible to be retained as factors, which represent approximately $77.532 \%$ of the variables retained in the factor. After rotating the sum of squared loadings and their related factor loadings, three factors are retained for analysis, which represent $65.59 \%$ of the variables retained in the factor.

Table 1 exhibits variables with significant loadings on the three factors retained in the study. Loadings greater than 0.40 are considered as significant loadings for purpose of this study. The variables are sorted by their loadings on each factor. A marked pattern of variables with high loadings for each factor is evident. The loadings for factor one range from 0.561 to 0.896 . The two loadings for factor two range from 0.856 to 0.866 . The loadings for factor three range from 0.512 to 0.787 .

Table 1: Factor Composition

\begin{tabular}{llc}
\hline & \multicolumn{1}{c}{ Factor Name } & Survey Questions \\
\hline Factor 1 & Preferred Assurance Provider & $6,11,12,13,15,16$ \\
Factor 2 & Usefulness of Assurance to Investor & 9,19 \\
Factor 3 & Propensity of Investor to Litigate for Losses & $2,7,10$ \\
\hline
\end{tabular}

3 Unless noted otherwise - scale responses of four and five are collectively referred to as "agree" responses, and responses of one and two are referred to as "fail to agree" responses for the remainder of the paper. 


\section{Analysis of the Participants' Responses to the Factors}

This section discusses limited business knowledge investors' responses to the statements in the survey retained in factors one, two and three. Prior to discussing the participants' responses to the survey questions that comprise each factor, a chi-squared test is incorporated to measure whether LBK investors perceive a difference between assurance offered by an audit and a review engagement. Consistent with expectations, participants do not perceive a significant difference between the assurance offered by a review and an audit engagement at the 0.05 level of significance $(\mathrm{p}=0.083)$. This result is expected, and confirms that LBK investors have a minimal knowledge of accounting practices and the range of services provided by CPAs.

\section{Factor One - Preferred Assurance Provider}

Factor One measures LBK investors' preference of the level of independence associated with the assurance provider who opines on a company's voluntarily reported nonfinancial information. Each of the survey items have squared loadings greater than 0.70 , which indicates that more than $50 \%$ of the variance in the original variables is explained by the factor.

Overall, more participants fail to agree (69.9\%) than agree (30.1\%) that they would hire the same CPA firm to design and review a company's continuous reporting system and to perform their financial statement audit (survey item 11). When asked to respond to this same question with respect to a company in which participants would invest their retirement income, participants responses to survey item 12 exhibit a fairly normal distribution. However, more participants fail to agree (66.6\%) than agree (33.4\%) that this assurance arrangement is suitable for a company in which they invest their disposable income (survey item 13). Finally, approximately 53.6\% of participants agree that a company's management team can review their own continuous reporting system as effectively as an outside CPA Firm, compared to $43.4 \%$ of participants that fail to agree (survey item 16).

Survey items 6 and 15 also address investors' preferences of the provision of assurance on voluntarily reported nonfinancial information. Thirty percent $(30.0 \%)$ of the participants $(30.0 \%)$ indicate that they would use a company's voluntarily reported nonfinancial information, regardless of whether the information is assured (survey item 6). Approximately forty-three percent (43.3\%) of the participants in survey item 15 agree that they their decision to purchase continuous assurance depends on whether they invest in a large or small company. Collectively, these results indicate that both small- and large-size companies should consider using some form of assurance to validate any voluntarily reported nonfinancial information that they communicate to the investors.

In summary, the results from factor one suggest that LBK investors' preference as to whether a nonindependent CPA should provide continuous assurance on a company's voluntarily reported nonfinancial information depends on the type of investment undertaken by the investor. LBK investors may be more tolerant of this type of assurance arrangement for their long-term investments, but not necessarily for their short-term investments. Also, LBK investors appear to believe that management may be in a better position to review the quality of their own continuous monitoring system than an outside accounting firm. Investigations as to why LBK investors do not strongly prefer an independent CPA is an area for future research.

\section{Factor Two - Usefulness of Assurance to Investor}

Factor Two addresses the usefulness of continuous assurance to investors. Participants' response to survey item 9 suggests that more participants agree $(60.0 \%)$ than fail to agree $(40.0 \%)$ that assurance on a company's nonfinancial information is useful in their investment decisions, regardless of whether a CPA who provides this assurance is independent. In addition, an overwhelming majority of the participants (83.3\%) indicate that they would desire more frequent assurance on the quality of a company's nonfinancial information for companies in which they invest their short-term profits (survey item 19). 


\section{Factor Three - Propensity of Investor to Litigate for Losses}

Factor Three addresses LBK investors' perceptions of their propensity to sue a client for mistakes in their voluntarily reported information. An overwhelming majority of participants $(80.0 \%)$ indicate in survey item 2 that their investment decisions would be better if a company voluntarily provides them with nonfinancial reporting information, even if that information is not subject to review by a CPA. Strikingly, almost $60 \%$ of LBK investors do not expect to win a lawsuit against a company if they incur financial harm as a result of this voluntarily reported information (survey item 7). These results are particularly mystifying in light of the fact $56.6 \%$ of the participants indicate that they would possibly file a suit against a company if they incur financial harm as a result of a company's required financial statement disclosures (survey item 10).

These results suggest that a firm may be more apt to consider investing in a continuous reporting information system that provides voluntarily reported nonfinancial information to investors. However, this may be of concern to accounting regulators, who may be compelled to provide regulation to prohibit firms from managing their disclosures by closing loopholes that may allow firms to shift some of their required financial statement disclosures to their voluntary nonfinancial information disclosures.

\section{CONCLUSION}

This study examines limited knowledge investors' perceptions of the provision of continuous assurance on a company's voluntary, XBRL-generated nonfinancial disclosures. Extant research identifies the need to understand LBK investors' determinants of expanded assurance on voluntarily reported XBRL-generated nonfinancial information. The results of this study reveal two very important findings. First, LBK investors' desire voluntarily reported nonfinancial information to assist them in their investment decision making. While the generalizability of the results to other investor groups may be limited, the implications suggest that companies may feel a level of comfort knowing that LBK investors do not feel that they would win a lawsuit against the company for a mistake in their voluntarily reported information.

Secondly, LBK investors do not find it appropriate for the same CPA firm to design and review a company's continuous reporting system if the CPA firm also audits the company's financial statements. Specifically, LBK investors do not believe that the provision of nonindependent assurance on a company's voluntarily-reported nonfinancial information will improve the quality of their investments with respect to their disposable income. These findings do not support Taylor et al.'s (2003) reliability framework.

\section{AUTHOR INFORMATION}

Reginald Wilson, Ph.D., teaches undergraduate classes in the area of Financial Accounting and Intermediate Accounting. In May 2003, he received his license to practice as a Certified Public Accountant in the state of Tennessee. His practical experience includes serving as an Auditor with Arthur Andersen for nearly two years. He also has extensive experience in the healthcare industry, serving as both a Financial Analyst and a Manager of Finance and Operations during his five year tenure in the Healthcare Industry. Dr. Wilson's primary research interests are centered on the role of auditor independence in audit quality and financial accounting quality.

\section{REFERENCES}

1. Ackert, L. F., and B. K. Church. (1998). The effects of subject pool and design experience on rationality in experimental asset markets. The Journal of Psychology and Financial Markets, 2(1) 6-28.

2. Akerlof, G. A. (1970). The market for "lemons": Quality uncertainty and the market mechanism. Quarterly Journal of Economics, 84(3) 488-500.

3. Allee, K. D., and T. L. Yohn. (2009). The demand for financial statements in an unregulated environment: An examination of the production and use of financial statements by privately held small businesses. Accounting Review, 84(1) 1-25.

4. Alles, M. G., A. Kogan, and M. A. Vasarhelyi. (2002). Feasibility and economics of continuous assurance. Auditing: A Journal of Practice \& Theory, 21(1) 125-138. 
5. Alles, M. G., and M. G. Gray. (2012). A relative cost framework of demand for external of XBRL filings. Journal of Information Systems, 26(1) 103-126.

6. Birnbaum, M. H., and S. E. Stegner. (1979). Source credibility in social judgment: Bias, expertise, and the judge's point of view. Journal of Personality \& Social Psychology, 37(1) 48-74.

7. Bhattacharya, N., E. L. Black, T. E. Christensen, and R. D. Mergenthaler. (2007). Who trades on pro forma earnings information? The Accounting Review, 82(3) 581-619.

8. Boylan, S. J. (2000). Using experimental asset markets to illustrate the value of auditing. Issues in Accounting Education, 15(1) 43-65.

9. Cotter, J. F., and S. W. Peck. (2001). The structure of debt and active equity investors: The case of the buyout specialist. Journal of Financial Economics, 59(1) 101-147.

10. Dawes, J. (2008). Do data characteristics change according to the number of scale points used?. International Journal of Market Research, 50(1) 61-77.

11. Dopuch, N., and R. R. King. (1991). Experimental Tests of Auditing as a Credibility Generating Mechanism. Vancouuver, B.C., Canada: The Canadian Certified General Accountants' Foundation.

12. Elliott, W. B., F. D. Hodge, J. J. Kennedy, and M. Pronk. (2007). Are M.B.A. students a good proxy for nonprofessional investors? Accounting Review, 82(1) 139-168.

13. Gay, G., P. Schelluch, and A. Batnes. (1998). Perceptions of messages conveyed by review and audit reports. Accounting, Auditing and Accountability Journal, 11(4) 472-495.

14. Gibbins, M., and B. Pomeroy. (2007). Reflections on continuous reporting and auditing. Accounting Perspectives, (3) 291-304.

15. Givoly, D., C. K. Hayn, and S. P. Katz. (2010). Does public ownership of equity improve earnings quality? Accounting Review, 85(1) 195-225.

16. Gompers, Paul A. (1995). Optimal investment, monitoring, and the staging of venture capital. Journal of Finance, 50(5) 1461-1489.

17. Harsha, P. D., and M. C. Knapp. (1990). The use of within- and between-subjects experimental designs in behavioral accounting research: A methodological note. Behavioral Research in Accounting, 2(March) 5062.

18. Hasan, M., P. J. Roebuck, and R. Simnett. (2003). An investigation of alternative report formats for communicating moderate levels of assurance. Auditing: A Journal of Practice \& Theory, 22(2) 171-187.

19. Hasan, M., S. Maijoor, T. J. Mock, P. Roebuck, R. Simnett, and A. Vanstraelen. (2005). The different types of assurance services and levels of assurance provided. International Journal of Auditing, 9(2) 91-102.

20. Healy, P. M., and J. M. Wahlen. (1999). A review of the earnings management literature and its implications for standard setting. Accounting Horizons, 13(4) 365-383.

21. Hermanson, D.R., and L.E. Rittenberg. (2003). Chapter 2: Internal Audit and Organizational Governance. in Research Opportunities in Internal Auditing 2003. edited by Bailey, A.D., Audrey A. Gramling, and Sridhar Ramamorti. Altamonte Springs, FL: The Institute of Internal Auditors Research Foundation.

22. Hirst, D. E., L. Koonce, and J. Miller. (1999). The joint effect of management's prior forecast accuracy and the form of its financial forecasts on investor judgment. Journal of Accounting Research, 37(3) 101-124.

23. Hodge, F. D. (2001). Hyperlinking unaudited information to audited financial statements: Effects on investor judgments. The Accounting Review, 76(4) 675-691.

24. Hovland, C. I., I. L. Janis, and H. H. Kelley. (1953). Communication and Persuasion. New Haven, CT: Yale University Press.

25. Huffman, A., and J. Crump. (2005). Applying continuous controls monitoring for achieving compliance and business improvement. Financial Executive, 21(8) 54-56.

26. Hunton, J. E., E. G. Mauldin, and P. R. Wheeler. (2008). Potential functional and dysfunctional effects of continuous monitoring. Accounting Review, 83(6) 1551-1569.

27. Hunton, J. E., A. M. Wright, and S. Wright. (2004). Continuous reporting and continuous assurance: opportunities for behavioral accounting research. Journal of Emerging Technologies in Accounting, 191 102.

28. Hunton, J. E., A. M. Wright, and S. Wright. (2007). The potential impact of more frequent financial reporting and assurance: user, preparer, and auditor assessments. Journal of Emerging Technologies in Accounting, 4 47-67.

29. Hunton, J. E., and R. A. McEwen. (1997). An assessment of the relation between analysts' earnings forecast accuracy, motivational incentives and cognitive information search strategy. Accounting Review, 72(4) 
497-515.

30. International Standard on Assurance Engagements. ISAE No. 100; International Auditing Practices Committee; 2001, New York, NY : International Federation of Accountants.

31. King, R., G. Pownall, and G. Waymire. (1990). Expectations adjustment via timely management forecasts: Review, synthesis, and suggestions for future research. Journal of Accounting Literature, 9 113-144.

32. Lerner, Josh. (1995). Venture capitalists and the oversight of private firms. Journal of Finance, 50(1) 301318.

33. Lindberg, D. L., and F. D. Beck. (2004). Before and after Enron: CPAs' views on auditor independence. CPA Journal, 74(11) 36-39.

34. Masters, R. (1989). Study examines investors' risk-taking propensities. Journal of Financial Planning, 2(3) 151-155.

35. Mercer, M. (2004). How do investors assess the credibility of management disclosures? Accounting Horizons, 18(3) 185-196.

36. Miller, P. B. W. (2002). Quality financial reporting. Journal of Accountancy, 193(4) 70-74.

37. Monroe, G. S., and D. R. Woodliff. (1994). An empirical investigation of the audit expectation gap: Australian evidence. Accounting \& Finance, 34(1) 47-74.

38. Olsen, R. A. (1997). Investment risk: The experts' perspective. Financial Analysts Journal, 53(3/4) 62-66.

39. Pany. K., and C. H. Smith. (1982). Auditor association with quarterly financial information: An empirical test. Journal of Accounting Research, 20(2) 472-481.

40. Pawlicki, A. (2008). AICPA Assurance Services Executive Committee Whitepaper: The shifting paradigm in business reporting and assurance. April 28. Available at: http://www.aicpa.org/Research/StudiesandPapers/DownloadableDocuments/AICPA_ASEC_Whitepaper_F inal_20082008April_2008.pdf

41. Pinsker, R., and P. Wheeler. (2009). The effects of expanded independent assurance on the use of firminitiated disclosures by investors with limited business knowledge. Journal of Information Systems, 23(1) 25-49.

42. Simunic, D. A., and M. T. Stein. (1987). Product Differentiation in Auditing: A Study of Auditor Choice in the Market for Unseasoned New Issues. Buraby, British Columbia: The Canadian Certified General Accountants' Research Foundation.

43. Slovin, M. B., M. E. Sushka, and C. D. Hudson. (1990). External monitoring and its effect on seasoned common stock issues. Journal of Accounting and Economics, 12(4) 397-414.

44. Taylor, M. H., F. T. DeZoort, E. Munn, M. W. Thomas. A proposed framework emphasizing auditor reliability over auditor independence. Accounting Horizons, 17(3) 257-266.

45. Vasarhelyi, M. A., and X. Zheng. (2013). XBRL mandate: Thousands of filing errors and so what? Journal of Information Systems, 27(1) 61-78.

46. Williams, P. A. (1996). The relation between a prior earnings forecast by management and analyst response to a current management forecast. Accounting Review, 71(1) 103-115. 


\section{APPENDIX A}

\begin{tabular}{|c|c|c|c|c|c|c|c|}
\hline \multicolumn{8}{|c|}{ Views Regarding An Investor's Needs For Assurance Services On Voluntarily Reported Non-Financial Information } \\
\hline & Mean & $\begin{array}{l}\text { Standard } \\
\text { Deviation }\end{array}$ & $\begin{array}{l}\text { Strongly } \\
\text { Disagree }\end{array}$ & Disagree & Neutral & Agree & $\begin{array}{c}\text { Strongly } \\
\text { Agree }\end{array}$ \\
\hline $\begin{array}{l}\text { 1. There is not a major difference between a } \\
\text { review or audit engagement. }\end{array}$ & 2.9231 & 1.0926 & $10.3 \%$ & $20.7 \%$ & $31.0 \%$ & $34.5 \%$ & $3.4 \%$ \\
\hline $\begin{array}{l}2 \text { As a future (or current) investor, I feel as if } \\
\text { my investment decisions would be better if } \\
\text { companies would provide me with voluntary } \\
\text { nonfinancial information, even if that } \\
\text { information is not audited or required by } \\
\text { regulation. }\end{array}$ & 4.0370 & 1.0184 & $3.3 \%$ & $3.3 \%$ & $13.3 \%$ & $40.0 \%$ & $40.0 \%$ \\
\hline $\begin{array}{l}\text { 3. I feel as if a company's voluntarily reported } \\
\text { non-financial information would be more } \\
\text { useful to me if the quality of the information } \\
\text { is verified by an assurance service, even if the } \\
\text { company's has only received unqualified } \\
\text { audit reports. }\end{array}$ & 4.1154 & 0.6528 & - & - & $13.8 \%$ & $58.6 \%$ & $27.6 \%$ \\
\hline $\begin{array}{l}\text { 4. I would take risks with my retirement money } \\
\text { if there were a } 50 \% \text { chance of a big payday. }{ }^{1}\end{array}$ & 2.4444 & 1.0860 & $16.7 \%$ & $40.0 \%$ & $23.3 \%$ & $13.3 \%$ & $6.7 \%$ \\
\hline $\begin{array}{l}\text { 5. I would take risks with my "extra" money if } \\
\text { there were a } 50 \% \text { chance of a big payday. }{ }^{1}\end{array}$ & 3.8462 & 0.6748 & & $3.4 \%$ & $20.7 \%$ & $62.1 \%$ & $13.8 \%$ \\
\hline $\begin{array}{l}\text { 6. I would purchase a company's voluntarily } \\
\text { reported non-financial information to assist } \\
\text { me in my financial decision making even if it } \\
\text { is not subject to the same regulatory process } \\
\text { as the "regular" financial statement } \\
\text { information. }\end{array}$ & 2.8889 & 1.1209 & $16.7 \%$ & $16.7 \%$ & $36.7 \%$ & $26.7 \%$ & $3.3 \%$ \\
\hline $\begin{array}{l}\text { 7. I would expect to win a lawsuit against a } \\
\text { company that makes an honest mistake when } \\
\text { the company voluntarily reports non-financial } \\
\text { information that is not required in the } \\
\text { financial statements. }\end{array}$ & 3.1111 & 1.1209 & $10.0 \%$ & $23.3 \%$ & $26.7 \%$ & $33.3 \%$ & $6.7 \%$ \\
\hline $\begin{array}{l}\text { 8. One CPA designs a company's voluntary } \\
\text { nonfinancial reporting system and reviews } \\
\text { the quality of the system; the other CPA only } \\
\text { reviews the system's reporting quality. Both } \\
\text { CPAs have an equal chance of losing a } \\
\text { lawsuit if the company commits fraud. }{ }^{1}\end{array}$ & 3.4815 & 0.9352 & - & $20.0 \%$ & $20.0 \%$ & $50.0 \%$ & $10.0 \%$ \\
\hline $\begin{array}{l}\text { 9. In reference to previous question, I believe } \\
\text { that either CPA firm that provides assurance } \\
\text { is equally valuable to me in helping me make } \\
\text { investment decisions. }\end{array}$ & 3.7778 & 0.8006 & - & $3.3 \%$ & $36.7 \%$ & $40.0 \%$ & $20.0 \%$ \\
\hline $\begin{array}{l}\text { 10. I WILL sue a company if their mandatory, } \\
\text { regulated disclosures include a mistake. }\end{array}$ & 3.4815 & 0.9755 & $3.3 \%$ & $10.0 \%$ & $30.0 \%$ & $43.3 \%$ & $13.3 \%$ \\
\hline $\begin{array}{l}\text { 11. I am willing to hire the same CPA firm that } \\
\text { designs the company's voluntary reporting } \\
\text { system to (1) authenticate the quality of that } \\
\text { system and (2) to audit that company's } \\
\text { financial statements. }\end{array}$ & 2.9259 & 1.0350 & $3.3 \%$ & $33.3 \%$ & $33.3 \%$ & $23.3 \%$ & $6.7 \%$ \\
\hline $\begin{array}{l}\text { 12. For a company in which I invest my } \\
\text { "retirement money" it just makes sense that } \\
\text { the same CPA firm that designs the } \\
\text { company's voluntary reporting system to (1) } \\
\text { authenticate the quality of that system and (2) } \\
\text { to audit that company's financial statements. }\end{array}$ & 2.8519 & 1.2620 & $13.3 \%$ & $26.7 \%$ & $26.7 \%$ & $23.3 \%$ & $10.0 \%$ \\
\hline
\end{tabular}


(Appendix A continued)

\begin{tabular}{|c|c|c|c|c|c|c|c|}
\hline & Mean & $\begin{array}{l}\text { Standard } \\
\text { Deviation }\end{array}$ & \begin{tabular}{|l|} 
Strongly \\
Disagree
\end{tabular} & Disagree & Neutral & Agree & \begin{tabular}{|c|}
$\begin{array}{c}\text { Strongly } \\
\text { Agree }\end{array}$ \\
\end{tabular} \\
\hline $\begin{array}{l}\text { 13. For a company in which I invest my } \\
\text { "disposable income" it just makes sense that } \\
\text { the same CPA firm that designs the } \\
\text { company's voluntary reporting system to (1) } \\
\text { authenticate the quality of that system and } \\
\text { (2) to audit that company's financial } \\
\text { statements. }\end{array}$ & 2.8148 & 1.1779 & $10.0 \%$ & $33.3 \%$ & $23.3 \%$ & $26.7 \%$ & $6.7 \%$ \\
\hline $\begin{array}{l}\text { 14. My decision to require a CPA to verify the } \\
\text { quality of a company's voluntarily reported } \\
\text { nonfinancial information would depend on } \\
\text { whether I invest a small or large amount of } \\
\text { money. }\end{array}$ & 3.1111 & 1.2195 & $6.7 \%$ & $30.0 \%$ & $16.7 \%$ & $33.3 \%$ & $13.3 \%$ \\
\hline $\begin{array}{l}\text { 15. My decision to require a CPA to verify the } \\
\text { quality of a company's voluntarily reported } \\
\text { nonfinancial information would depend on } \\
\text { whether I invest in a large company or a } \\
\text { smaller company. }\end{array}$ & 3.0000 & 1.2089 & $10.0 \%$ & $26.7 \%$ & $20.0 \%$ & $33.3 \%$ & $10.0 \%$ \\
\hline $\begin{array}{l}\text { 16. I am confident that a company whose } \\
\text { management team rigorously evaluates the } \\
\text { authenticity of their voluntarily reported } \\
\text { nonfinancial information is as effective as if } \\
\text { an outside CPA Firm provides the same } \\
\text { service. }\end{array}$ & 3.3333 & 1.0000 & $3.3 \%$ & $20.0 \%$ & $20.0 \%$ & $53.3 \%$ & $3.3 \%$ \\
\hline $\begin{array}{l}\text { 17. My perception of a company's voluntarily } \\
\text { reported nonfinancial information would be } \\
\text { enhanced if the quality of the information is } \\
\text { verified by a CPA who only performs an } \\
\text { audit for companies where I have retirement } \\
\text { stock. }{ }^{1}\end{array}$ & 3.0370 & 1.0554 & $3.3 \%$ & $26.7 \%$ & $40.0 \%$ & $20.0 \%$ & $10.0 \%$ \\
\hline $\begin{array}{l}\text { 18. My perception of a company's voluntarily } \\
\text { reported nonfinancial information would be } \\
\text { enhanced if the quality of the information is } \\
\text { verified by a CPA who only performs an } \\
\text { audit for companies where I engage in day- } \\
\text { trading activities. }\end{array}$ & 3.1111 & 0.9740 & $3.3 \%$ & $16.7 \%$ & $53.3 \%$ & $16.7 \%$ & $10.0 \%$ \\
\hline $\begin{array}{l}\text { 19. If I am investing my money for short term } \\
\text { profits, I would like to have more frequent } \\
\text { assurance of the accuracy of the financial } \\
\text { and nonfinancial information of a company } \\
\text { in which I invest. }\end{array}$ & 4.0370 & 0.5175 & - & - & $16.7 \%$ & $70.0 \%$ & $13.3 \%$ \\
\hline $\begin{array}{l}\text { 20. Companies who are mandated to provide } \\
\text { more frequent financial information will not } \\
\text { be as likely to commit accounting fraud. }{ }^{1}\end{array}$ & 3.5185 & 1.2207 & $6.7 \%$ & $10.0 \%$ & $33.3 \%$ & $26.7 \%$ & $23.3 \%$ \\
\hline 21. I consider myself a beginner investor. ${ }^{1,2}$ & 4.0741 & 1.0715 & & $13.3 \%$ & $13.3 \%$ & $33.3 \%$ & $40.0 \%$ \\
\hline 22. I consider myself a professional investor. ${ }^{1,2}$ & 2.0000 & 1.3009 & $43.3 \%$ & $26.7 \%$ & $10.0 \%$ & $13.3 \%$ & $6.7 \%$ \\
\hline \multicolumn{8}{|c|}{$\begin{array}{l}{ }^{1} \text { Denotes that this item was not included in either of the three factors } \\
{ }^{2} \text { These items served as a manipulation check to ensure that participants paid close attention to the items in the survey. } \\
\text { Participants who recorded the same answer for each question were removed from the statistical analysis. } \\
\text { Note: The sum of Likert Scale percentage may not equal } 100.0 \% \text { due to rounding. All mean and standard deviations are } \\
\text { rounded to four decimal places. }\end{array}$} \\
\hline
\end{tabular}




\section{NOTES}

